\title{
Hemolytic anemia due to glutathione reductase deficiency
}

INSERM

\section{Source}

INSERM. (1999). Orphanet: an online rare disease and orphan drug data base. Hemolytic anemia due to glutathione reductase deficiency. ORPHA:90030

Haemolytic anaemia due to glutathione reductase (GSR) deficiency is characterised by nearly complete absence of GSR activity in erythrocytes. 